Mercator, Fortaleza, v. 16, e16009, 2017.

DOI: https://doi.org/10.4215/rm2017.e16009

ISSN: $1984-2201$

Copyright @ 2002, Universidade Federal do Ceará

\title{
REAL ESTATE MARKETING IN THE LIGHT OF COMMODITY AESTHETICISM
}

\author{
BARBOSA, Adauto Gomes ${ }^{\text {* }}$
}

(a) Phd in Geography, lecteur Instituto Federal de Pernambuco/ (IFPe). http://lattes.cnpq.br/2054823458163234

\section{(*) CORRESPONDING AUTHOR}

Address: Instituto Federal de Pernambuco - Avenida Professor Luiz Freire, CEP: 50740540, Recife (PE), Brasil. Tel: (+55 81) 21251796. E-mail: adautogb@gmail.com

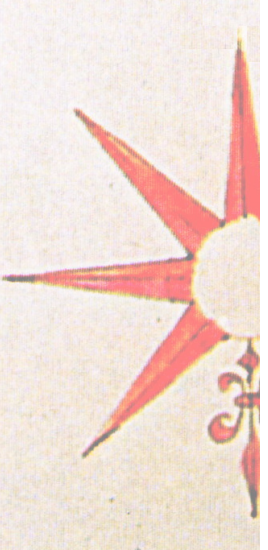

\begin{abstract}
The real estate marketing of the Reserva do Paiva, of the metropolitan region of Recife (RMR) is analyzed from the perspective of commodity aestheticism, alluding to the metaphor of the death logic that permeates the action of capital, which permanently seeks to age objects and things, arguing that they should be replaced by novelties in the market. In this context, planned obsolescence is discussed in the light of aesthetic innovation, even if in the real estate sector this meets with certain difficulties due to the long durability of properties. With the emphasis on socio-spatial exclusiveness, this real estate complex is advertized as a new urban rarity, strategically located in one of the few unbuilt beachfront areas in the metropolitan space. In the light of commodity aestheticism, marketing explores both the rational and the emotional sides through co-branded actions, materials and advertising in magazines aimed at the luxury consumer, with recurrent discursive constructions that appeal to the idea of sophistication and exclusivity. This is equally related to the needs of our time, such as convenience, comfort, safety and environmental sustainability.
\end{abstract}

Keywords: Commodity aestheticism; Socio-spatial exclusivism; Death logic; Reserva do Paiva.

\section{RESUMO/ RESUMEN}

\section{O MARKETING IMOBILIÁRIO À LUZ DA ESTÉTICA DA MERCADORIA}

O marketing imobiliário da Reserva do Paiva, na região metropolitana do Recife, é analisado na ótica da estética da mercadoria, aludindo-se à metáfora da lógica de morte a permeiar a ação do capital, que, de forma permanente, busca envelhecer objetos e coisas sob o argumento de serem substituídos pelas novidades do mercado. Nesse contexto, a obsolescência programada é abordada à luz da inovação estética, mesmo que no setor imobiliário isso encontre certas dificuldades pela alta durabilidade dos imóveis. Na tônica do exclusivismo socioespacial, esse complexo imobiliário é anunciado como uma nova raridade urbana, situado estrategicamente em uma das poucas áreas à beira-mar ainda não edificadas no espaço metropolitano.À luz da estética da mercadoria, o marketing explora tanto o lado racional quanto o emocional, por meio de ações de co-brands, matérias e publicidade em revistas voltadas para o consumo de luxo, com recorrentes construções discursivas a apelarem à ideia de sofisticação e exclusividade, igualmente relacionado com as necessidades do nosso tempo, como comodidade, conforto, segurança e sustentabilidade ambiental.

Palavras-chave: Estética da mercadoria; Exclusivismo socioespacial; Lógica de morte; Reserva do Paiva.

\section{EL MARKETING INMOBILIARIO A LA LUZ DE LA ESTÉTICA DE LA MERCANCIA}

El marketing inmobiliario de la Reserva de Paiva, de la región metropolitana de Recife (RMR), es analizado en la óptica de la estética de la mercancía, aludiendo a la metáfora de la lógica de la muerte que permea la acción del capital, la cual, de forma permanente, busca envejecer objetos y cosas sobre el argumento de que deben ser sustituidos por las novedades del mercado. En este contexto, la obsolescencia programada es abordada a la luz de la innovación estética, mismo que en el sector inmobiliario esto encuentre ciertas dificultades por la alta durabilidad de los inmuebles. En la tónica del exclusivismo socio-espacial, ese complejo inmobiliario es enunciado como una nueva raridad urbana, situado estratégicamente en una de las pocas áreas a la orilla del mar, aún no edificadas en el espacio metropolitano. A la luz de la estética de la mercancía, el marketing explota tanto el lado racional como el emocional, por medio de acciones de co-brands, materias y publicidad en revistas tornadas para el consumo de lujo, con recurrentes construcciones discursivas que apelan la idea de sofisticación y exclusividad, siendo esto igualmente relacionado con las necesidades de nuestro tiempo, como: comodidad, confort, seguridad y sostenibilidad ambiental.

Palabras clave: Estética de la mercancía; Exclusivismo socio-espacial; Lógica de muerte; Reserva do Paiva. 


\section{INTRODUCTION}

Marketing is a key component of the real estate business. Just as in other branches of the economy, in this sector it is present throughout the cycle, that is, from market research in the pre-project design phase, until the delivery of the final product to the customer. It is responsible for identifying needs and defining the concepts of the products to be launched. Through marketing, the social metabolism of capital reveals itself in all its splendor, in a process in which goods are meticulously designed and disseminated to awaken and sometimes fulfill wishes; at the same time inciting their transformation into new needs. Like so many other goods real estate is part of this game of seduction under the most diverse artifices and appeals.

In this context, marketing always works with the dimensions of the aestheticism of the commodity, that "[...] designates a complex functionally determined by the exchange of value and originating from the final form given to the commodity, concrete manifestations and sensual relations between the subject and object conditioned by them" (HAUG, 1997, p. 15). Based on this, this article analyzes the real estate marketing of the Reserva do Paiva from the perspective of commodity aestheticism, alluding to the metaphor of the death logic that permeates the action of capital, which permanently seeks to age objects and things arguing that they should be replaced by novelties in the market.

The aforementioned real estate megaproject is a Real Estate, Residential and Services Complex (RRSC) and is located on the southern coast of the metropolitan region of Recife (RMR), in the municipality of Cabo de Santo Agostinho. It is an eminently exclusivist development in terms of its target clientele. The income levels of the envisioned clientele for the properties of the first Reserva do Paiva releases correspond to the AA and AAA segments, ${ }^{1}$ which as reported by the project's developers correspond to the income levels of those who earn from 55 to 110 minimum wages, respectively. This very high level justifies speaking of socio-spatial exclusivism.

The RRSC's first two projects were completed in 2010 - the Condominium Morada da Peninsula and Via Parque, ${ }^{2}$ although the master schedule foresees the completion of the last phase only around 2040. ${ }^{3}$ In addition to this condominium, the only one made up of houses, at present, the residential Vila dos Corais and Terraço Laguna has been completed; a business center with 1,118 rooms for offices, attached to a shopping center (open mall) with 40 commercial rooms; a Sheraton hotel and a gastronomic complex. In this frame of reference, the tone of exclusiveness prevails in the Reserva do Paiva which is positioned as a new rarity in the context of the MRR, strategically located in one of the few unbuilt areas on that metropolitan coast.

It is worth noting that the Reserva do Paiva is part of a new context of production of urban space, in which the action of capital no longer restricts itself to the production of individual enterprises, but also increasingly produces real estate complexes that comprise large fragments of the city, which have a plurifunctional land use and are very segmented in terms of the target customer. Bold actions such as legal instruments like public-private partnerships also constitute new conditionings of this capitalist production of the metropolis, often mired in contradictions between the luxury RRSCs, designed for high solvency demands and the persistence of basic problems in the city

\footnotetext{
The market works with different income classes. Class 'A' has a monthly income higher than 20 minimum wages; class 'B', between 10 and 20 minimum wages; class ' $C$ ', 4 to 10 minimum wages; class ' $D$ ', between 2 and 4 minimum wages; and class 'E', with a monthly income below two minimum wages. (GUIMARÃES, 2007 apud SANTANA, 2013). In the case of Reserva do Paiva, the monthly family income needed to purchase the highest standard property is around 110 minimum wages, well above the aforementioned classification. For didactic purposes and considering that both the developer and brokers reported on the income needed to purchase property in Reserva do Paiva, it is considered that an AA segment ranges from 50 minimum wages and AAA, more than 110 minimum wages, according to the generic standard adopted by the brokers who sell this real estate megaproject.

2 A toll road built by a public-private partnership is the only one that gives access to the RRSC and is also the shortest route linking Recife to the Suape complex and the resort of Porto de Galinhas.

3 As informed by the entity that manages the complex, the last phase of the RRSC is expected to conclude, precisely, in 2042 , as announced by the developer responsible, even if it is not possible to carry out an exercise in futurology, as this will depend heavily on macroeconomic market conditions.
} 
as a whole. In this framework, the discursive constructions designed or powered by marketing are misleading about urban reality in various ways. Based on this, below there follows an analysis that focuses on the insertion of marketing in the light of commodity aestheticism, as introduced above.

\section{COMMODITY AESTHETICISM IN REAL ESTATE MARKETING}

It is assumed that goods have social relations of production and, therefore, as well as expressing social work, products and brands are icons of the consumer society of our time, with the purpose of converting everything into merchandise. Thus, more and more the figure of the consumer overrides that of the citizen, because according to Milton Santos (1997), nowadays we live in a festival of signs and images and all this confuses rather than helps explain reality. This logic of capital means the victory of exchange value over use value, with the possibility of using a bait for the viability of the exchange.

Thus, when constructing signs, advertising plays a key role as a component of marketing that incorporates poetry, literature and other artistic and cultural expressions as ingredients of its rhetoric. Advertising (and moreover, marketing in its entirety):

Becomes therefore the actual ideology of this society, each "object", each "good" unfolds in a reality and an image as an essential part of consumption. Both signs and objects are consumed: signs of happiness, satisfaction, power, wealth, science, technology etc. [...] The sign is bought and sold; language becomes a value of exchange. (LEFEBVRE, 2001, p. 69, emphasis added).

Thus, to try and reduce urban reality to these signs, as do property developers and the relevant departments and marketing consultants who act for them, means seeing the city and its space as goods and not a human work in the broad sense. There comes a point where things and products become brands and they conceal reality, becoming a hyper-reality in the terms anticipated by Lipovetsky (2012).

Nowadays, the spaces produced by commodity aestheticism, although multiple and geographically distant, carry with them many similarities regarding the processes and actions that concoct them. Thus, also on the level of the space designed and produced, marketing is essential to awaken new meanings, images and representations, as the sign of well-being, beauty and happiness. Within the real estate sector, this is confused with sophistication, differentiation and exclusivity.

For this perspective, what Lipovetsky calls hypercapitalism is in force, where almost everything becomes "hyper", with frequent launches of products and brands, generally advertised as novelties, which also move to meet new desires and new needs. In this framework:

This is a new consumer economy that plays the role of "hyper" in all things: ever more gigantic (hypermarkets and unusually large shopping centers); always faster (online shopping); increasingly easier credit and household debt [...] more and more high quality brands, spending on luxury goods; in generic terms, objects, trends, travel, music, games, and theme parks, in addition to communication, images, artwork, movies, and TV series (LIPOVETSKY, 2012, p. 18, emphasis added).

In the wake of this consumer society, commodity aestheticism is increasingly imbued with signs, patterns and the evocation of the lifestyles linked to behavior directed toward consumption as an individual achievement, prestige and social acceptance. According to Santana (2013, p. 74): "There is a transition from the need to survive to desire, of status for the various kinds of services provided to individuals, bringing them affective compensations". Thus it is as part of this daily game that the properties are offered to customers. In fact, when announced, real estate is not sold just as "real estate", but as a set of signs that consign status and a lifestyle that can be translated as 
a form of social inclusion. All this creates a commitment that appeals more to subjectivity than to business rationality.

In this intertwining of reason and emotion:

[...] The market bases itself on the discourse of man's "new needs" to introduce new features and add value and differential to its product. New needs can be of various orders: physical, social, spatial, locational, a return to nature, security, leisure, services, costs, and forms of payments, among others (SANTANA, 2013, p 89, emphasis added).

From this, real estate developments are marked by discourse and practices that seek at all costs to convince the potential buyers that these needs will be met through the purchase of the property in question. In fact, the role of marketing is not exactly to meet needs but to create them, and as soon as some are created others have to be invented to continue this perverse and uncontrollable movement of the socio-metabolism of capital, as proposed by Mészáros (2002). So the main issue is the structural need of reproduction for capitalist accumulation, whose ethics are guided by the justification for expanded reproduction itself.

From the point of view of commodity aestheticism, as proposed by Haug (1997), the game of consumer seduction goes far beyond the tangible dimension and, therefore, market agents resort to symbolic and abstract elements, exploring the idea of happiness, merit, pleasure and individual rewards. Through an amorous aesthetic courtship marketing affects the emotional side of customers much more, since in this context the act of purchase translates as the very threshold of the pursuit of happiness and self-fulfillment. Indeed, "the ideal of commodity aestheticism is to manifest what pleases us the most, what we say, what we seek, what we have not forgotten, what everyone wants, what we have always wanted" (HAUG, 1997, p. 78). It is in this sense that corporations develop images and slogans for their products that touch us less by reason and more by emotion.

In this regard, according to Kotler (2003), a rational appeal gives greater possibilities for the competition to quickly offer another product as good or even better. However, sensitizing the emotional side and engaging through the sensory field, marketing suggests experiencing supposedly unique experiences that lead people to feel more beautiful, desirable, prestigious or even enviable. This emotional appeal is increasingly present in real estate, including through the symbolism of the house in Brazilian society, identified as part of personal fulfillment, conferring prestige and status. As stated by Caldeira (2000, p. 264), "Through their homes, residents develop a discourse through which they speak both of society and of themselves." When it comes to luxury real estate, created in city spaces conceived of as noble, this is much stronger in terms of the discursive construction of the seller and the buyer, that is, the two poles of commodity aestheticism.

Moreover, from the viewpoint of capital, the city is widely disseminated by marketing at the service of the interests of real estate developers through the cost-benefit ratio. Criticizing such a vision, Carlos (2001: 106) points out: "Thus the reductive reading of the city ends space in an Euclidean dimension, and from this perspective, space turns into distance, a passage, which would nullify itself by time imposed as speed (also emptied of meaning). "“

It is with this reductionist view of cost-benefit that the "patchwork" of metropolitan space is compared, always aiming to evoke the aging of some and the innovation of others. Real estate marketing does this all the time because at the service of capital, space is reproduced as a commodity that is generalized, as it is through installments that marketing is able to generate accumulation and its motto proposes new layouts, new locations or any other novelties. 


\section{SOCIO-SPATIAL EXCLUSIVISM AND THE DEATH LOGIC}

First, it is valid to say that marketing uses a number of techniques and strategies that go beyond the simple advertising of products; it induces behavior patterns and assigns concepts to goods, according to the profile of the target customer. That is:

Marketing strategies and the statements of advertisements aimed at commercialization and consumption will have a style befitting the public they are intended for. Meanings will be produced for the subjects, turning their dreams into plausible realities. This creates a language of seduction, in which certain elements are selected according to the profile of the target segment. Keywords that are highlighted in statements and images that speak for themselves. (SANTANA, 2013, p. 41).

Thus, in Reserva do Paiva, as stated by one of the executives interviewed," "the campaigns $[\ldots]$ of projects are [...] strictly differentiated in their graphic art and the standard of filming", as this is part of the process of "enchanting" the client or through the prism commodity aestheticism, a loving courtship. Before even seeing the property close up, the graphic and media material needs to make the best impression possible to encourage the creation of a very positive image and arouse the desire for the commodity, after all, to use a very common and sometimes trite jargon "first impressions last."

As an expression of this, the project's main slogan returns to the rational and says: "Planned neighborhoods are a trend, the Reserva do Paiva is already a reality" (Figure 1). In this case, there is evidence of a certain visionary approach on the part of the developers in deciding to invest in a branch of business, which is advertised as an innovative investment in the context of Recife's real estate with an implicit appeal for people to follow this trend and not be left behind. In the case of Reserva do Paiva, the appeal is mainly to exclusivism, translated through high purchasing power and its common stereotypes.

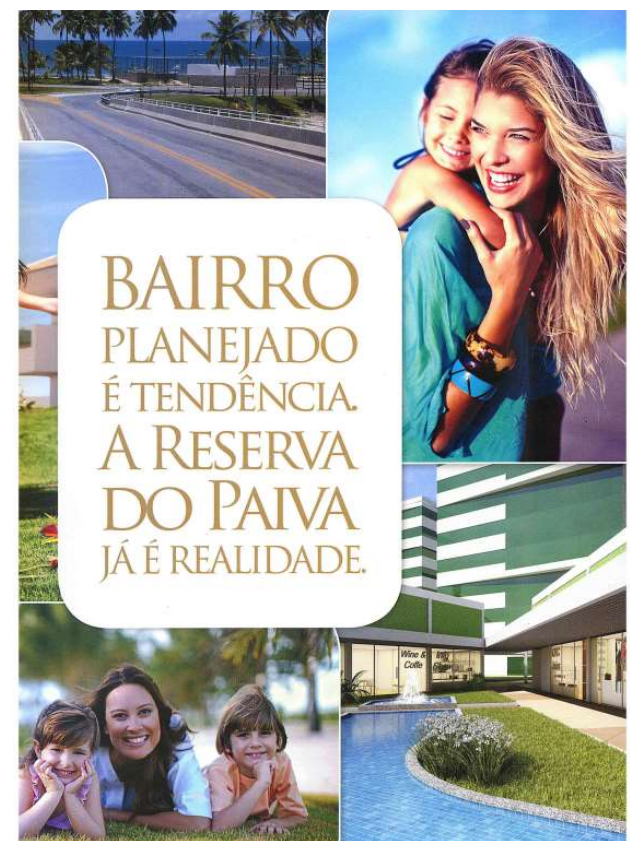

Figure 1 - Poster displaying the main slogan of Reserva do Paiva's advertising (Trad. "Planned neighborhoods are a trend, the Reserva do Paiva is already a reality").

Source: Odebrecht Real Estate Developments, 2014.

\footnotetext{
4 Of the 35 interviews conducted for the study, 05 of them were with executives of the corporations developing the RRSC, as well as 13 with executives linked to other important companies and the body representing Recife's real estate sector, as a way to provide a more detailed and consistent analysis of this real estate megaproject.
} 
In the sales prospecting, a second slogan is presented with a friendlier, more emotive tone "Living with the Reserva do Paiva standard. You can. You deserve it". So when it refers to an alleged "Reserva do Paiva standard" it seeks to differentiate this product from others on the market, affirming its unique exclusive character, thus positioning itself as a spatial rarity. Then, the merchandise is presented to the client as possible and something they deserve. Incidentally, it is quite common to associate expensive products and services as a form of personal worth. If a priori needs are seen as something collective, with the notion of entitlement, at least in the sense of this slogan, just the opposite seems to occur.

In turn, one advertisement for the Varanda do Parque Condominium shows a young white mother, with a middle-class profile, smiling together with an equally smiling son amid the following sentence: "If you could fulfill three wishes, what would be the other two be?". With a similar image, the billboard advertising Vila dos Corais states: "Vila Coral, a dream come true."

On the front pages of a special issue on real estate, the magazine Revista Negócios PE, displayed an aerial image of the condominium with the following sentence: "For those who chose Vila Coral, the Reserva do Paiva is already a reality." Below the image is another phrase: "A New Reference for the Market in Pernambuco. Visit and marvel " (Figure 2). In all these slogans, dreams are translated into desires and can become a reality, provided that one buys this real estate product.

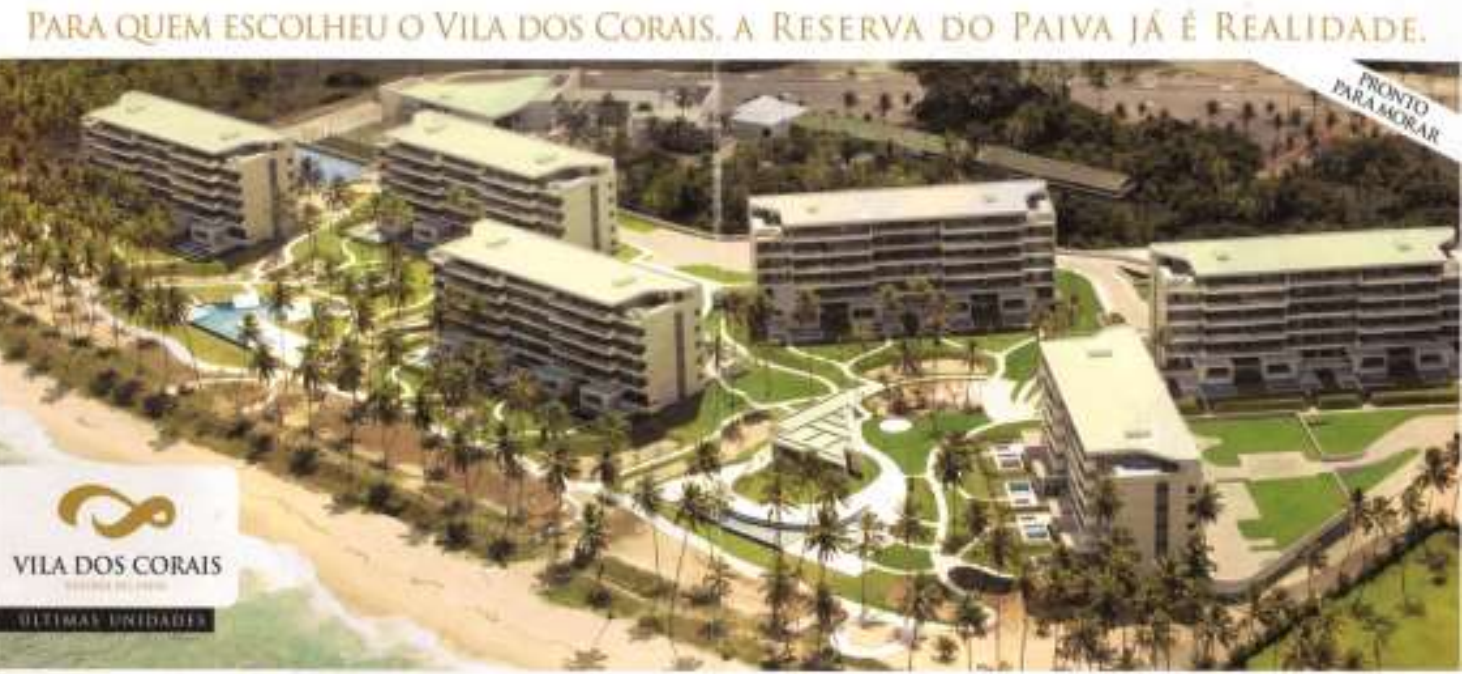

UMA NOVA REFERENCIA PARA O MERCADO DE PERNAMBUCO.

Figure 2 - Advertisement for the Village Coral Condominium and its slogans.

(Trad. \&quot;For those who chose Vila dos Corais, the Reserva do Paiva is already a reality."

"A new reference for the market in Pernambuco. Visit and marvel."

Source: Revista Negócios PE, year 5, n. 28, May-Jun. 2013.

Another fairly common recurrence in marketing is the exchange of the "old" for the "new", which is fully inserted in the field of aesthetic innovation. Even though there is some difficulty in materializing this with real estate, because of the peculiarities of property, such as the long durability of the goods and their being fixed to the ground, they also fall within the planned obsolescence process (HAUG, 1997) but the obsolescence does not occur through the physical deterioration of the building. Instead new aesthetic models are proposed for houses and apartments and their layouts built in accordance with the so-called new lifestyles and services that translate into comfort and convenience.

In addition, advertising products in specialized segments of the media is the best way to reach the target audience. As an expression of this, in the magazine Revista Class Casa, a specialized publication in the architecture and interior design industry, aimed at the high income clientele, a report on the Village Coral Condominium points out that on Boa Viagem Avenue one can only have, at the most, a sea view, whereas in this enterprise, the apartments have two balconies, one facing the sea 
and one facing the forest (VILA DOS CORAIS..., 2013). That is, advertising the products as well as having journalistic reports in specialized magazines is another very fruitful marketing strategy in the luxury segment. It is also a way to reach a specific audience, which is a great disseminator of the typical socio-cultural values of the consumer society.

It also evokes a new urbanity and in this case one of the strong selling points of the Reserva do Paiva's marketing is the promotion of the possibility of an urban life "in which people have the pleasure of living there, to live in the streets, to circulate, and think in fact of a different neighborhood", as stated by one of the executives responsible for this real estate complex. Thus, the implementation of this RRSC is part of a dialectical movement in which, on one side, are the rich neighborhoods, quite vertical and having urban centrality, but saturated in the face of the negative externalities that such phenomena have, and on the other, the "solution" would be to escape to a space that is designed and sold as a "planned neighborhood" or "new city", or even a "new ideal city" materialized by this venture.

In this way, the discursive construction that touts the superior qualities of Reserva do Paiva is embedded with representations of space and involves symbolism and codes related to the "death" of Boa Viagem (and other similar neighborhoods), which is most often the neighborhood negatively contrasted with the Reserva do Paiva in the real estate marketing, This is a contradiction, as currently Boa Viagem has the most expensive square meter in Recife.

It is necessary to "kill" the city to "give birth to the new" (that is, the Reserva do Paiva) that has much superior qualifying attributes. Based on this, it is argued that capital works on a logic of death in which "killing" or confronting the negative elements of the reality of the noble spaces, justifies the "birth" of a new space or "new neighborhood", as this real estate complex has been repeatedly considered by real estate developers, the media and even the State.

A contradictory element in all this is that in this dialectical movement the metropolis becomes a "necropolis" (SANTOS, 1997), to the extent that its space is produced and continuously reproduced from "successive murders." Under this line of reasoning, the market needs to "kill" or age what already exists to deliver the new. As the focus of this analysis is based on the marketing sphere, it goes without saying that much of what is advertised as new has within itself the old, because, in a sense, the new is merely a discursive construction, that is, it is part of the dimension of commodity aestheticism.

This implies that the confrontation with the real city or some of its fragments would be the key to the success of a real estate development. It is exactly by confronting the neighborhood of Boa Viagem, for example, that the RRSC Reserva do Paiva affirms and justifies itself from a marketing perspective. In the process of valuation based on space, marketing plays a crucial role in the signification and re-signification of metropolitan areas. It is a process of creative destruction as proposed by David Harvey, a disposable society in force, for which: "It means more than throwing away goods produced [...]; it also means being able to throw off values, lifestyles, stable relationships, attachment to things, buildings, places, people and ways of acting and being. " (HARVEY, 1992, p. 258). We must recognize that this phenomenon is an intrinsic part of the production of urban space in the current period.

To extol the basics, which strictly speaking each city should have, such as security, lighting and urban cleansing, sidewalks, parks and many other components, is also a way for marketing to positively differentiate Reserva da Paiva from Recife's noble (but deficient) spaces. At the limit, strengthening the discourse about violence and insecurity helps to show the alleged positive qualities of the product being sold. It can be observed through this logic of death that capital enables the production of a new space, slices it into interchangeable cells and makes it a salable and highly valued commodity in the context of the capitalist city.

Behind this line of argument lies a strong discursive contradiction, which is that the more you advertise the new as something essential and inevitable, existing objects and things are "dead" to 
be promptly replaced. Thus, beyond a creative destruction, as proposed by Harvey (1992), nowadays there seems to be a much more destructive logic of production (MÉSZÁROS, 2002). In this sense, regarding this logic of death, the discourse is often structurally contradictory, as it cites Boa Viagem as the benchmark upscale neighborhood, however, recurrently it deconstructs its image of urban life, heralding the Reserva de Paiva as something far superior. The following words are a good illustration of this:

[...] in fact it is much more like trying to create another Boa Viagem, the stretch that connects the Domingos Ferreira [Avenue] [...] to the seafront [...] which, in a way, thinks about the integration of spaces, that lowers the walls, creates wide sidewalks that are cared for by the city, which has adequate street lighting, which has public security, which has a neighborhood structure that works. (Executive of the Developer in an interview given on 26 September 2013).

Without intending herein to deny the many problems found in Recife's neighborhoods where the social strata with higher purchasing power live, it is evident that the tone of the discourse of Reserva do Paiva's developers presents it as "another Boa Viagem" or "another Casa Forte" but with a fully functioning infrastructure and urban services and a supposedly homogeneous social content marked by the sign of exclusivity. Thus, socio-spatial exclusiveness, skillfully addressed in the marketing as a supposed synonym of internal social homogeneity, is always placed as a substantive issue as an attribute of valuation and the quality of life.

\section{BRANDS AND OBJECTS OF DESIRE FOR OSTENTATION, LUXURY, SECURITY}

In the context of the RRSC Reserva do Paiva, the key elements of the marketing are the items and services offered in the luxury properties, which are presented as a reality apart, something rare, unique and that only a few have the privilege to enjoy. In the houses, the biggest appeal is the architectural differentiation, which in the case of the Condominium Morada da Peninsula, offers no less than 30 different projects for 66 homes, all signed by renowned professionals in the market.

According to the magazine Revista Class Casa, the Vila dos Corais' apartments have up to 5 parking spaces, which are in a partly subterranean floor so as not to hinder pedestrian traffic or pollute the visual landscape with cars (VILA DOS CORAIS..., 2013 ). In the common areas there are gardens with gazebos designed as an extension of the beach. It also mentions items such as pools with individual decks, a beach club with a gourmet space, a sauna, party-room, nightclub, cinema, games room, playroom, gym, and spa, well as tennis courts, five-a-side football pitches and sports support. In addition, they mention the running track and bike path, located in on a parallel track to the Via Parque, as urban facilities for the whole complex.

With regard to sales techniques, Reserva do Paiva's marketing uses local and traditional media, such as billboards, furnished show apartments, sales books, magazines and newspapers, media at airports, and television, among others. There is also relationship marketing, which involves direct communication with customers. The company has a database of customers that form a portfolio of select investors. An executive from the developer refers to this: "They like to feel privileged and we like to have them close." It is notable that this marketing method is preferentially carried out with the most desired customer, that is, big businessmen and persons of high social standing, who are invited to acquire property in Reserva do Paiva as an investment.

They are mobilized through actions such as co-branding that associates distinct brands with enterprises, usually at launch parties. Among the luxury brands involved in these marketing activities in Reserva do Paiva is the Italian Maserati, which produces luxury cars, and also the German 
Mercedes-Benz, where customers have a test drive and can buy the vehicle during the launch of the real estate. The same has happened with the jeweler H. Stern, as well as lunches and tasting fine wines in partnership with a restaurant specializing in this segment.

Thus, from the point of view of commodity aestheticism, appearance is something extremely important, after all, "What is just something, but does not look like a 'thing', is not salable. What seems to be something is salable. "(HAUG, 1997, p. 26-27). In this context, we live in the midst of a technocracy of sensuality, meaning "dominion over people exercised due to their fascination with technically produced artificial appearances" (HAUG, 1997, p. 67). This realm of appearances is directly related to the lifestyle embedded in the products sold.

If beyond the property a life style is being sold, the idea in this case is to establish co-brands with luxury brands. In this regard, Haug (1997, p. 30) states that "[...] an entire genre of goods throws loving glances at buyers imitating and offering nothing more than the same loving eyes with which the buyers try to woo their human objects of desire ". Within this frame of reference, nothing is more salutary than allying traditionally desired brands to the world of luxury real estate in the Reserva do Paiva. Another example of co-branding is visualized in Figure 3, which shows the completion of the sporting event called Suzuki Day at the Reserva do Paiva, in partnership with the Japanese car maker.

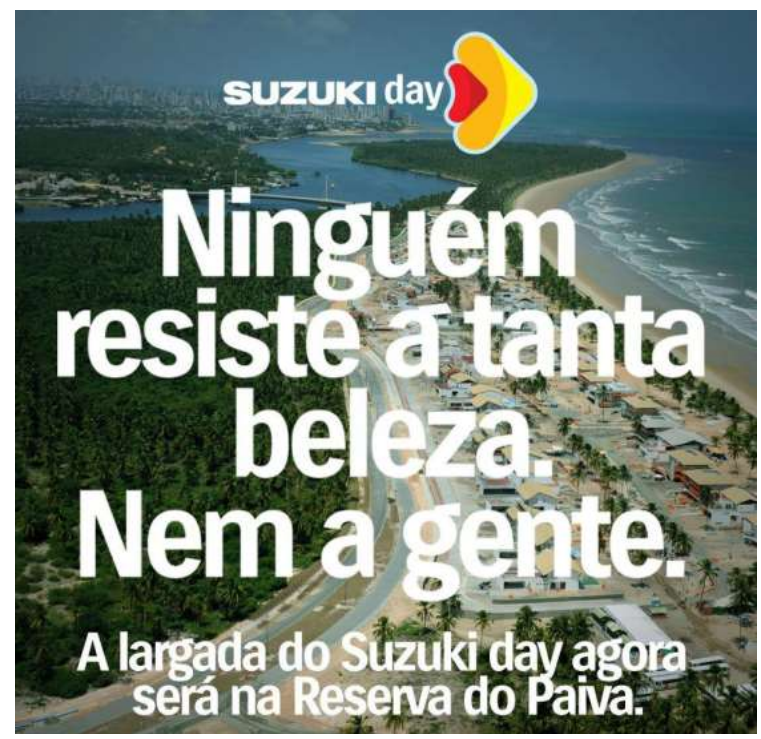

Figure 3 - Co-branding advertisement by Suzuki and Reserva do Paiva.

(Trad. "No one can resist so much beauty. Not even us. The start of Suzuki day will now be at the Reserva do Paiva. "Source: <http://www.marluscosta.com.br/suzuki-day-neste-domingo-28042013-na-praia-do-paiva/>.

From the point of view of commodity aestheticism, nothing is more logical than to approach these objects of desire to Reserva do Paiva's real estate products as a way of associating consolidated brands to add value to the enterprise by linking it to the high standard lifestyles embedded in these brands. This is also another way to demonstrate exclusivity and sophistication, as one of the directors interviewed affirmed: "[...] the concept that we are establishing is exclusiveness for all standards of apartment".

In other words, products that bear the Reserva do Paiva mark of are expertly crafted by marketing to add more value by focusing on differentiation and exclusivity; a typical appeal of the segments serving the high-end market. It is the constant search for differentiation through homogenization and not necessarily a differentiation in homogenization since, strictly speaking, however exclusivist the intention, it is impractical to provide a fully homogeneous space in its social content. In this case, in the real estate marketing plan, internal homogenization is more a promise of a supposedly classless social and economic content without class differences inside the complex, sold as if it were a haven amid the reigning hell in the metropolitan space, marked by numerous iniquities. 
Taking up the perspective of hyper-reality proposed by Lipovetsky (2012), it is worth noting that in the latest release of Reserva do Paiva, the scale model of the enterprise averages no less than 60 square meters, that is, larger than many compact properties offered on the market. In justifying this aggressive approach (in fact, quite a common term in the vocabulary of marketing), one of the directors said: "Because we understand that the client only understands what we propose [through the scale model] because what we propose does not exist in the city". It is implicit that the Reserva do Paiva's proposal as a new rarity is based on exclusiveness. In this hyper-real world it is also necessary to enchant customers through their eyes, a way to display ostentation and grandeur through an aesthetic appeal of extravagance in the visual field.

One of the points lauded by the property developers is the fact that the Reserva do Paiva has received two Master Property awards from FIABCI Brazil and Secovi-SP, in 2012, in the area of social responsibility, and the Vila Coral, in particular, was also awarded in 2013. In turn, the Reserva do Paiva also won the FIABCI Prix d'Excellence Awards Winners 2014, a French award where the winners of the Real Estate Master compete with real estate developments in other countries. To a large extent these awards signal the mainstream position of the value of production in Recife's real estate as represented by Paiva Reserve. Despite the truism, it is worth stressing that these awards are an important part of the marketing of this real estate complex.

Nevertheless, all the marketing actions aim at the creation and strengthening of the brand. This is clearly evident in the statement of a director of the developer "We are building a brand, which, fortunately, has already captured part of its value and I think it will capture [...] even more value. It is a process under construction". Thus, Santana says (2013, p. 48): "A brand has greater aggregate value the greater its intangible symbolic force, that is, the prestige that it can confer on people." In high end real estate, this implies the inclusion of several innovative items and leisure services in the homes, leading to a certain life style typical of the wealthier classes.

As noted throughout this analysis, one of the points of residential marketing that applies to the reality of Reserva do Paiva relates to luxury. Without intending to discuss luxury in-depth here, it is noteworthy that it is not something new in history and its senses and meanings change in each historical, social and geographical context. In the current period, luxury is marked by the proliferation of "[...] maximum protection devices, insured luxury residences guarded 24/7, villas endowed with walls, watchtowers, alarm systems and surveillance cameras" (LIPOVETSKY, 2005, p. 60). Incidentally, security is one of the items most taken into consideration when purchasing high end properties, according to an article on luxury real estate in the magazine Revista Day by Day (GÓMEZ, s.d.), another publication specialized in architecture and interior design, whose access to customers occurs mainly through its own specialized offices.

It is also no coincidence that for the current Brazilian society, safety is part of the corollary; in luxury real estate it is very recurrent. "Increasingly, a high level of security is becoming an important argument when offering luxury" (LIPOVETSKY, 2005, p. 61). For the real estate sector the element of security is undoubtedly a value attribute and this is one of the factors that makes it reasonable for the market to present certain parallels between the degree of monitoring (read: safety) and high end luxury real estate complexes.

In this sense, when one purchases a property one buys the complete package, with the promise of security being one of its main ingredients. Security is thus an intrinsic part of the real estate marketing strategy focused on high-income residents. In this hyper-modern world (LIPOVETSKY, 2005) (and why not amend: "hiper-violent"), the "new" housing model is based largely on the imperative of security. No wonder that in Reserva do Paiva, the company providing this service publishes monthly a report with all occurrences and the measures taken on the complex's website. It is more like a kind of police diary, reporting episodes by type (thefts, burglaries, placing tents on the beach, loud sounds from cars, attempted rape, etc.) and the respective measures adopted, either by diligently involving the authorities or by the management of the RRSC. 
Another point of Reserva do Paiva's marketing relies on an eulogy to nature, the environment and sustainability. According to Lipovetsky (2012, p. 25), "[...] numerous brands now build their identity on the basis of communication founded on sensory messages, ethical proposals and commitments to respect the environment." In a report on luxury properties, the magazine Revista Day by Day says: "More recently, sustainability has also begun to appear on the buyers' radar." (GÓMEZ,s.d., p. 56).

In Reserva do Paiva, in the attempt to be picked up by this "radar", the appeal is made through an ecological discourse beginning with the use of terms like reserve, coral, peninsula, sea, park, and palm trees, among others that refer to the notion of nature and the amenities of the place. Thus,

The ecological discourse that emerges in various corners of the planet produces an echo, as the market logic in real estate means that little or nothing pertains to real environmental preservation, since its action, most often, destroys nature to implement its concrete products. When the ecological discourse comes into play, is more palliative than proactive (SANTANA, 2013, p. 97).

In many cases, the discursive constructions that evoke respect for the environment and commitment to sustainability are critically called greenwashing because they create an image (only an image) of socially and environmentally responsible enterprises. Also according to the report in the Revista Day by Day, the value of luxury homes today is also linked to projects with the signature of renowned professionals, regarded as brands by the market (GÓMEZ, s.d, p. 56). Following this trend, in Reserva do Paiva, there is the combination of competent local and extra-local professionals.

As one of the executives interviewed said: "[...] We prioritize local architects, because there is always an aspect of tropicalization of everything, but we add some more modern components from outside that we don't always have here. "In this regard, the idea that there is clearly an inter-scalability in the production actions of real estate megaprojects is defended. Thus, the marketing associates the product with the best on a local level, but without losing sight of what is considered innovative elsewhere, including consultancies based in the Rio-São Paulo axis or the United States, Denmark, Argentina and Australia, or even consultancies based in Recife, but that have a broad scope and national recognition.

All consultant partners are recognized as designer labels and so having projects with their signature means assigning more value to the products, strengthening the brand. "Thus, the product concept is being replaced by the notion of the brand. These brands are a guarantee of product quality, which act as the signature of a name that distinguishes them. "(SANTANA, 2013, p. 47). It is the high degree of importance of brands that justifies paying so much for certain products. According to Haug (1997, p. 38): "The brand and the mediate and immediate promises of the value of use have absolutely no need to refer to the particular characteristics of the goods designated by it." In this sense, brands speak for themselves, as they tend to be more perennial than products, and it is this permanence that is envisioned by property developers for the thirty years during which they aim to develop the real estate complex in question.

\section{FINAL CONSIDERATIONS}

Based on the above, it is evident how marketing nowadays is increasingly aggressive in the process of increasing value to facilitate the process of accumulation and reproduction of capital. In the context of the high-end market, this aggressiveness translates into strengthening most of the concepts mentioned here, such as exclusivity, differentiation, luxury and a set of elements identified as flags of our times, such as security and sustainability.

One of the key elements that underlies the contradiction of the problem in context is that the implementation of luxury real estate complexes is evidence of the elitist attempt at differentiation 
through homogenization (and not a differentiation in homogenization, as this space is far from homogeneous), even if this attempt is a marketing ploy, given the difficulty of talking about social and spatial homogeneity, especially in an area with historical peculiarities of great inequalities like RMR.

Moreover, engendered by the logic of capital accumulation, the changes that occur from and / or due to this RRSC express the metamorphoses of the modern world (or hyper-modern, if you prefer), recurrently related to consumption for the sake of consumption, with the spread of new signs, values, behaviors and needs, in which the role of marketing is an instrument potentiating the accumulation process, in the face of the various appeals that it engenders in the consolidation of the aestheticism of merchandise.

In this sense, the landscape of the Reserva do Paiva becomes more and more monotonous as a space mathematically designed to be aseptic, predictable and salable, even with the most daring discursive construction, that competently appropriates marketing to impose the empire of exchange on use, in which nature and the environment are symbolically appropriated to strengthen the process of accumulation through real estate. The urban and architectural beauty is always highlighted with people's happiness at the privilege of being able to enjoy such exclusivity, giving the impression that the city could fully take place there.

Finally, it must be said that, despite the criticism that has been made herein about the role and the marketing strategies of Reserva do Paiva, this does not diminish the unquestionable quality of the RRSC in terms of its urban infrastructure and the construction materials used. In fact, from that point of view, to tell the truth, the Reserve even points to how the entire metropolitan area of Recife should be. However, this quality stands as another reinforcement of the allegory of the death logic examined above, under the scrutiny of commodity aestheticism, in a contradictory procedure in which, what is effectively at stake is the accumulation of capital, not improving life in the city as a whole.

\section{BIBLIOGRAPHIC REFERENCES}

CALDEIRA, Teresa Pires do Rio. Cidade de muros: crime, segregação e cidadania em São Paulo. Tradução de Frank de Oliveira e Henrique Monteiro. São Paulo: Ed. 34; Edusp, 2000.

CARLOS, Ana Fani Alessandri. Espaço-tempo na metrópole: a fragmentação da vida cotidiana. São Paulo: Contexto, 2001.

GÓMEZ, Natália. Imóveis de luxo: com economia aquecida e número crescente de milionários, o Brasil se destaca pelo bom momento do mercado de imóveis de alto padrão. Day by Day, ano 3, n. 3, p. 55-60, [s.d.]. HARVEY, David. Condição pós-moderna. Tradução de Adail Ubirajara Sobral e Maria Stela Gonçalves. 5. ed. São Paulo: Loyola, 1992.

HAUG, Wolfgang Fritz. Crítica da estética da mercadoria. Tradução de Erlon José Paschoal. São Paulo: Unesp, 1997.

KOTLER, Philip. Marketing de A a Z: 80 conceitos que todo profissional precisa saber. Tradução de Afonso Celso Cunha Serra. 14. reimpr. Rio de Janeiro: Elsevier, 2003.

LEFEBVRE, Henri. O direito à cidade. Tradução de Rubens Eduardo Frias. 5. ed., 2. reimpr. São Paulo: Centauro, 2001.

LIPOVETSKY, Gilles. O reino da hipercultura: cosmopolitismo e civilização ocidental. In: LIPOVETSKY, Gilles; JUVIN, Hervé. A globalização ocidental: controvérsia sobre a cultura planetária. Tradução de Armando Braio Ara. Barueri, SP: Manole, 2012.

LIPOVETSKY, Gilles. Luxo eterno, luxo emocional. In: LIPOVETSKY, Gilles; ROUX, Elyette. O luxo eterno: da idade do sagrado ao tempo das marcas. Tradução: Maria Lúcia Machado. São Paulo: Companhia das Letras, 2005.

MÉSZÁROS, István. Para além do capital: rumo a uma teoria da transição. Tradução de Paulo César Castanheira e Sérgio Lessa. Campinas, SP: Unicamp; Boitempo, 2002. 
SANTANA, Gisela. Marketing da "sustentabilidade" habitacional: lançamentos imobiliários e ecologia urbana: em busca do equilíbrio. Rio de Janeiro: Mauad X: Inverde, 2013.

SANTOS, Milton. Técnica, espaço, tempo: globalização e meio técnico-científico informacional. 3. ed. São Paulo: Hucitec, 1997.

VILA DOS CORAIS: jardim privado é o diferencial. Class Casa, n. 38, fev.-mar. 2013. Mercado imobiliário, p. 51-52. 